\title{
Young European's constructions of nation, state, country and Europe
}

National Identities 2020 22(1),

Doi 10.1080/14608944.2019.1694499

\author{
Alistair Ross \\ ORCID 0000-0001-5243-7704 \\ alistairrosslondon@gmail.com \\ a.ross@londonmet.ac.uk
}

London Metropolitan University, UK (Emeritus Professor)

Jean Monnet ad personam Professor

\begin{abstract}
This study addresses how young Europeans ( 11 to 19 years of age, 29 countries, $n=2000$ ) construct identities around their country and Europe, and how they discuss nationalism and national identities in their discourse. Based on empirical data collected through small group deliberative discussions ( $n=324$ ) in 29 states), young people's use of these terms were gathered in free-ranging and unstructured debate. Analysis suggests that a significant majority are sceptical about their 'national' identity, and about nationalism as being significant in their futures. While most have some sense of identification with their country and state, their location in increasingly diverse settings means that for many 'national' identities have little significance.
\end{abstract}

\section{Key words}

social construction, political identities, nation, state, young people 


\section{Young European's constructions of nation, state, country and Europe}

\section{Introduction}

Von hier und heute geht eine neue Epoche der Weltgeschichte aus, und ihr könnt sagen, ihr seid dabei gewesen

[From here and today begins a new epoch of world history, and you can say that you witnessed it]

von Goethe, 1822 (1999 p. 355)

Goethe's observation was made (in his later recollection) on the evening after the Battle of Valmy, on the $20^{\text {th }}$ September 1792, to a group of officers in the Prussian army, who had been

unexpectedly defeated that day by the French Republican army. Goethe was at the time a military observer for Duke Karl August of Saxe-Weimar-Eisenach. The French had advanced to shouts of 'Vive la Nation' and singing Ça Ira, the revolutionary ballad (Opello, 2016, p 108). Never before, in Goethe's estimation, had soldiers in an army declared that they were fighting for their nation, rather than for a leader or a monarch (Brubaker, 1996, p $1 \mathrm{fn} 1$ ). Unknown to Goethe, on the same day as the battle the Revolutionary Government in Paris had declared France to be an état civil, a civil state: 'from that moment on an individual could only exist as a citizen once his or her identity had been registered by the municipal authorities, according to regulations that were the same throughout the national territory' (Noiriel, 1996 [1988] xviii).

Since that time the nation state has been widely seen as the ubiquitous and significant political unit in international affairs. The term was often used by leading political scientists in the 1950s and 60s: Halle, for example, (1952) claimed that 'a prime fact about the world is that it largely composed of nation-states' (1952:10), and Rustow wrote of a world of '130 nations' (1967:282), including the nation-states of the USSR (sic) and the United Kingdom [sic]. But this interutilization of nation and state was problematic. Connor described the term nation as 'terminological chaos' (1993:112). He argued the nation-state barely existed, pointing out that most modern states contain significant national minorities (Connor, 1978a:382). He referred to a 1971 survey of 132 'entities generally considered to be states', suggesting that 120 of them had national minorities of a tenth or more, in 70 more than a quarter of the population were minorities, and 39 had more than half the population as 'minorities', and deplored 'the careless use of terminology ... the United Nations [is] an obvious misnomer' (1978b, pp 59-60). But the term nation remains embedded in popular discourse, bolstered by national myths (as shown in Western Europe and beyond by Hobsbawm and Ranger (1983), and in Eastern Europe by Hoskin and Schöpflin (1997)).

\section{Generational changes and national identities in contemporary Europe}

This article examines how young Europeans, aged between 12 and 19, are currently constructing nations and nationalism. It suggests that many of the generation born after about 1993 are developing a new and different understanding of nationalism, rather as Fulbook's (2011) analysis of twentieth century German young people showed that there are not only significant differences in the ways in which generations construct political ideas, but that these are the consequence of political fractures and dissonance in society. Young people's availability for political mobilisation is dependant on the 'time of transition with respect to the ways in which people can become involved in new regimes and societies' (Fulbrook 2011:488). This article suggests that the cohort of young Europeans born since the early 1990s will not simply turn towards their parents' views and constructions of 'the nation' as they age: they have a collective identity based on what Fulbrook defines as 'generationally defined common experiences' (2011:11). The age at which 
people experience key historical moments - in Fulbrook's study, the transitions within German society in 1933, 1945 and 1989 - can be critical: 'age is crucial at times of transition, with respect to the ways in which people can become involved in new regimes and societies' (2011:488). Key formative experiences do not 'necessarily produce similar outcomes, but common challenges at a particular life stage, and ... unresolved issues' produce generational difference (emphasis in original 2011:9).

There have been several formative experiences that have affected this generation: the technologies of the internet and social media, and the rapid increase in ethnic diversity, for example. By 2015, over 20 per cent of EU households included at least one immigrant, regardless of migration generation or migration background' (Agafiței and Ivan 2016:1), double the number in 2000. Two other political changes in Europe are particularly salient with respect to identification with the nation and nationalism: the ending of the Cold War divisions of the continent (and the realisation that many of the states of Eastern Europe would become members of the European Union), and the creation of a European citizenship in the Treaty of Maastricht in 1992. Article 8 of the Treaty reads

1. Citizenship of the Union is hereby established. Every person holding the nationality of a Member State shall be a citizen of the Union

2. Citizens of the Union shall enjoy the rights conferred by this Treaty and shall be subject to the duties imposed thereby.

(CEC 1992)The Treaty of Lisbon in 2008

added an explanatory clause to (1): 'Citizenship of the Union shall be additional to and not replace national citizenship' (CEC 2008).

This creation of a supranational construct of citizenship could be seen as the commencement of a 'new epoch', just as momentous as that noted by Goethe exactly 200 years earlier, as the Tindemans Report (CEC 1976) on the future of the European Union had foreshadowed:

Europe can and must identify itself with the concerted and better controlled pursuit of the common good ... We will then have created a new type of society, a more democratic Europe with a greater sense of solidarity and humanity.

(CEC 1976:11-12)

Duchesne (2008:405) observes that this new model of European political identity, as an imagined symbolic identity, drew on the constructivist analyses of national identity made by Anderson (1983) and Gellner (1983). Their work challenged the primordialist model of the nation, which saw nationalism as an essentialist construct based on attachment to common roots and heritage, into which an individual was born, with particular traditions, rituals, language or religion. The nation was seen as ancient and natural (Herder, 2002; Van den Berghe, 1978). But, as Brass observes, 'there are very few groups in the world today whose members can lay any serious claim to a known common origin': it is not actual descent, but a belief in a common descent (Brass 1979, 35).

The social constructionist view of national identity, developed particularly by Gellner and Anderson, sees it as a subjective term, used to create a distinctive category. National identities become the construction of bonds based on presumed shared group ideas, cultural artefacts and emotions. Anderson (1983) describes such national identities as Imagined Communities, inventions or constructions that had their own particular narrative power, ... because the members of even the smallest nation will never know most of their fellow members, meet them, or even hear of them ... The nation is imagined as limited because even the largest of them, encompassing perhaps a billion living human beings, has finite, if elastic, boundaries, beyond which lie other nations. (Anderson 1983:6)

The nation thus becomes a narrative: Bhabha (1990) suggests that 'the cultural temporality of the nation inscribes a much more transitional social reality ... as a system of cultural signification, as 
the representation of social life rather than the discipline of social polity' (Bhabha:1-2). But Brubaker has observed that the construction of the European Union 'was supposed to be the graveyard of the nation-state and modern nationalism ... yet far from moving beyond the nationstate, fin-de siècle Europe has been moving back to the nation state ... into a score of nationally defined states' (Brubaker 1996, p c4, emphasis as in original). He was writing here particularly with the states formed from the disintegration of the USSR, Yugoslavia and Czechoslovakia: the impact of this on young people's sense of nationalism in the successor states will be discussed in the analysis below.

So the question this article addresses is how do young Europeans, members of the generation whose lives have been wholly within the trans-national times of a European citizenship and the supranational consequences of this, construct such terms as the nation and national identity? What narratives do they construct around the state they live in, around Europe, around 'the nation'?

\section{Methodology}

How an individual constructs a concept such as nation or nationalism takes place in a social setting, and is an activity that is contingent on the particular circumstances in which the concepts are expressed. Most young people of school age are particularly difficult to questions about their understanding of a particular term, not least because they are accustomed to many of the questions they are asked by adults as being intended to test their knowledge. The majority of questions put to young people in schools are closed: the questioner knows the 'correct' answer, and the role of the young person is provide this as a response.

This was a personal post-retirement research project that began in 2010 (Ross, 2015, 2019). Its principal objective was to examine the ways in which young people in mainland Europe, between the ages of 11 and 19, constructed identities for themselves that might include such entities as their country and Europe. I visited over 104 different towns, cities and villages (with populations between 500 and 13 million) in 29 European countries, and in each engaged in discussions with small groups of young people, talking with some two thousand of them in 324 conversations. I anticipated that most people do not necessarily have firm or fixed senses of identity, and how an individual chose to describe their identities was depend on the specific context (Bruter, 2005; Balescu, 2009; Anthias, 2012).

My approach was to initiate small group deliberative discussions (usually about 50 minutes long), in which usually between five and eight young people could feel they were in command of the subject matter, and would discuss terms with each other, using their own vocabulary, rather than acting in response to a questioner. Open-ended questions were asked, often in response to what had been said, in order to encourage them to talk about the way that they saw their attachment to their locality, country, nation and state, and other possible locations that might represent a form of political identities. This apparent lack of structure was designed to capture and use the narratives the young people themselves. To that end, I would (for example) always initial refer to your 'country', allowing them the opportunity, if they chose, to introduce terms such as 'state' and 'nation'. Only when and if this had been done might I enquire what they meant by such terms, through asking for examples and contexts.

The research technique of group conversations (gruppendiskussionsverfahren: group discussion method) has been developed over in German social science investigations over the past twenty years (Bohnsack 2000, Loos and Schäffer, 2001). It has been described as 'an open interview, 
intended to let respondents develop a topic in their own language, in their symbolic system and their relevant framework,' and to permit analysis that 'avoid[s] projecting ... meanings that are not appropriate (Bohnsack, 2000: 21, translated by Scheunpflug et al. 2016). Gugglberger et al. (2015) suggest this more open and elastic method when compared to more structured focus groups (2015). 'Respondents can set the structures and contents of the conversation by themselves' Scheunpflug et al. (2016 10), allowing them to produce 'implicit, action-guiding knowledge ... based and acquired in fundamental experiences ... that groups of individuals share with each other' (Wagener 201892). This was used in this study by providing narrative-generating stimuli that initiated discussion, beginning with immanent issues - the accounts and language group members used in their narratives - and only moving to exmanent questions when they had had developed structures relevant to them. Most discussions were largely in English: I was on every occasion accompanied by a local colleague, usually a social science academic, who would interpret either occasional phrases, or sometimes whole conversations.

In order to establish a sense of agency, in which the discussion was directed and paced by the group, they were assured at the outset that there were no 'right' answers, and they should say if they disagreed with each other. Strategies to generate this were:

- $\quad$ not to introduce leading terminology

- $\quad$ to make questions transparently open (If they said they were French, I might respond

'What makes you French?')

- $\quad$ to accept all responses as valid

- $\quad$ where possible, to construct questions that were responding to what they had said

- $\quad$ to ask as few questions as possible

- $\quad$ not to expect everyone to respond (not a sequential interview); and

- $\quad$ to ask for examples.

There was an initial tendency in many discussions for individuals to conform with the other members of the group: this rapidly changed as I accepted diverse comments, and asked if there were any disagreements. There were very rarely arguments, but sometimes robust exchanges of view: there did not appear to be occasions where views were supressed to conform to the norm.

I had extensive networks and contacts in European universities, which I used to find usually two schools or colleges in each location (one in a middle class residential area, one in a working class area). Consent was obtained from school principals, and written consent from the young people's parents (all of those under 16, and older in some countries) and from the young people themselves. All names used here are pseudonyms. The first phase of fieldwork (2010-12) covered the countries that had joined the EU after 2004ㄹ: a second phase (2014-16) added many of the pre-2004 members ${ }^{2}$. At least two places were visited in each country, and four or more in the larger countries. The young people participating were diverse: some 56 per cent were female, about half had parents in working class occupations. There were minority-origin young people in many discussion groups, reflecting the distribution of minorities in each country and Europe as a whole: by country of origin, 76.8 per cent had parents and grandparents from the country they were living in: of the remainder, 7.4 per cent had at least one parent/grandparent from another EU country, 8.4 per cent from a European country not in the EU, and 7.4 per cent from outside Europe (this data is based on what was volunteered in discussion). Not intended to be a statistically representative sample, it nevertheless gathered a range of potential views across each

\footnotetext{
${ }^{1}$ Bulgaria, Croatia, Cyprus (Republic), Cyprus (Turkish Republic of), Czech Republic, Estonia, Hungary, Iceland, Latvia, Lithuania, North Macedonia, Poland, Romania, Slovakia, Slovenia, Turkey

${ }^{2}$ Austria, Belgium, Denmark, Finland, France, Italy, Germany, Luxembourg, the Netherlands, Norway, Portugal, Spain, Sweden, Switzerland. Note that the Greece, the Irish Republic and the United Kingdom were not included in the study)
} 
country: from different regions, social backgrounds and cultural origins. Much empirical social science research draws its subjects from a narrow base: Arnett (2008) estimates that 80 per cent of non-USA studies are drawn from psychology undergraduates in the capital city of a country. These are extrapolated as representative of the country (Rozin, 2001). Rochat suggests that many studies stress the universality of their findings, and 'to relegate diversity to noise rather than as a primary object of study' (Rochat, 2010: 107). This study was intentionally noisy, reflecting the diversity of these countries: with many locations beside the capital city. Within the constraints that the population being sampled was of young residents of these European countries (largely industrialised, democratic and comparatively rich), the sampling was designed to avoid the pitfalls analysed by Henrich et al. (2010).

All discussions were recorded, and transcribed in full. The analysis that followed was partly grounded in the data itself - an iterative, inductive and comparative process (Glaser and Strauss 1967; Charmaz and Belgrave 2010), but also explored specific theses identified from the literature. The themes that were particularly relevant for the analysis presented in this article were the distinction between cultural and civic components of identity (drawing on Anderson 1983; Brubaker 1996; Bruter 2005; Joppke 2010), generational differences (Lutz et al. 2006; Fulbrook 2011); and the use of continuities and contingent resources (Ekström 2016). There was also some country-specific literature: all these were combined into a meta-analysis (Rabiee 2004:657).

Most of the young people (about 95 per cent) made a more than minimal contribution to the discussions, and about two thirds were fully participant. The conversations were varied in focus and emphasis, and my questions varied in response to their issues and vocabulary, so the mode remained conversational rather than interrogatory. This made responses difficult to quantify. Most discussions were in English, the others simultaneously translated by my local colleague.

\section{Results}

Having introduced myself - as a British researcher studying young people's sense of identity in a number of European countries - I asked them to each begin by describing their own identity. This was partly a device to ensure everyone made a contribution at an early stage, but it also resulted in many of them describing themselves by referring to a country, or two or more countries. For example, in a Danish group of 16 and 17 year olds in the small city of Odense, Agnethe ( $\%$ ) and Lilli (\%) introduced themselves as Danish girls, and Cæcilie (\$) agreed, but added 'I feel - very Danish - even though my grandfather immigrated from Scotland'. At this, Julius ( $\sigma^{\prime}$ ) observed by saying they had said that they were Danish, rather than European: 'so ... we are nationalists', which provoked general amusement. Evald $\left(\sigma^{\top}\right)$ too said he felt Danish, 'but my father, and my grandfathers, my grandmother, they emigrated from Germany, so I also feel some connection with Germany - but I feel mostly Danish'; and finally Hussein ( $\left.\sigma^{\prime}\right)$ explained that his parents had come from Palestine, 'I' $m$ born and raised in Denmark - I don't feel as quite as Danish as the others, I feel more a bit of both - I feel more European than Danish - it's like the same culture as Arabic.'

Such points provided an opportunity to ask why they felt Danish, or 'mostly Danish', and this provoked (in this group, and in many others) discussion of a variety of explanations, that usually appeared to being generated at the moment, rather than having been thought about before. Place of birth was suggested (though many of those who had migrated said not), the country they were living in and whose culture they had grown up in, how they had been brought up, the language they spoke - but this was often with some awareness of its transience: Lilli said 'When I say I feel Danish it's not like I feel that I belong in this country, I could easily move to another country.' Hussein commented 'people often mistakenly say that there is a clash of cultures, that the youngster doesn't know where to put himself. Is he German or Danish or Palestinian or 
something? But I see different cultures as being an advantage- you take the best of both cultures, the best of both identities and make your own - that's an advantage, from my point of view.'

At this point, Julius said that his sense of being Danish meant he had 'a lot of people that you feel connected to in that way... when you're abroad you can find Danish people and then you feel at home. I'm aware that it's a social construction, and that until the eighteenth century you wouldn't have had nationalities in the sense that you have it now - and I try to look away from nationalities.' Cæcilie saw nationality as 'a way of expressing ourselves when we're abroad', but she felt 'European as well, because we have some fair rules and stuff that unites us.'

Such an opening discussion was not atypical, and often included the suggestion that citizenship and nationality were a Imatter of chance: thus in Sevilla, Sancho (o'14) said 'it's a lottery ... if you are born there, you love your country, and agree with the rules ... then you are Spanish.' But in Prilep, Lazar ( $0^{\prime} 18$ ) thought that he had had a poor deal: 'we are all Macedonians, but not by our choice - we are unlucky to be born here. I wish I was born in Denmark because here we are surrounded by poverty, by corruption, and the unemployment rate is high.' Similar points have been argued by Shachar (2009) and Joppke (2010): the latter observed that, far from the Enlightenment construct of the modern state being 'based on a contract, the state is not a voluntary association' (2010 p 16).

The concepts of the nation and the state thus constitute a field, in Bourdieu's sense as a setting in which different social positions are held and interact: these concepts are not unitary or fixed, but differentiated and possibly competitive stances that interact to determine legitimacy over the capital of citizenship (Bourdieu 1984; Brubaker 1996, 61). This section now examines the empirical evidence for the various positions and constructions of 'the nation' and 'the state' taken by these young people. I first consider the broad range of positions taken; then the points that were largely held in common by the majority of young people, before concluding with the significant contextual variations thrown up in particular states.

\section{Competing constructions}

These were brought to the fore in responses to my asking if there were things that they liked or disliked about what they had described as 'their' country. In a Swedish group of sixteen year olds in Stockholm, Saga ( $($ ) said she was 'thankful for being Swedish, well, being born in Sweden because we have great health care, living in Sweden is pretty good, the basic stuff, the basic human rights.' But she qualified this: the definition of who was Swedish or not had become politicised by 'what the nationalist - and pretty racist - movement is doing now - defining who's Swedish and who's not Swedish.' Christin (\%) said she 'won't be proud of Sweden as a whole - I'll be proud of where I grew up, and my family, and the areas that I lived in ... and feel affection towards that - but ... [not] Sweden as a whole. .. it is weird to talk about Sweden as "your country"'. Margreta (\%) said that 'this nationalistic movement [Sverigedemokratern] ... [has] become very serious - I don't want to be whatsoever identified with them ... it's become important to not identify myself with where I live, or where other people are from.'

Others, generally a minority, and often some of those from particular states, had a more essentialist view of the nation and their nationality. For example, some young people of Serbian origin spoke of 'their blood'. In Slagelse, in Denmark, Kanko (o'15) put it: 'I'm not Danish - if you want to, you can feel Danish if you're not born Danish - but I feel more like Serbian, because it's in my blood - I'm connected with Denmark because I live here.' Similar sentiments were expressed by some young Turks. In Çanakkale, Bugra (o'14) said that to be Turkish depended on his 'ideological view, on the person's racial [iksal: blood lineage] background,' and in the same group Kaan ( $\left.0^{\prime} 13\right)$ defined 'the Turkish man is the person who can sacrifice their life for their country, and 
the woman is the supporter of her man.' Comparable essentialist views were expressed by a minority of those of migrant origin: in Brussels, Hassan ( $0^{\prime 15}$ ) said 'I think I'm Belgian because I was born here, and I grew up here - but in blood, I'm always Moroccan - I'll never forget that and I'm proud of it.' And in Estonia, some characterised and othered the Russkiye (Russianspeaking/origin minority) in similar terms: Merilin (\$12) said 'they have this kind of temperament. It's in their blood. They are brave and courageous, and they can't do anything about it'. The essentialist stance was also sometimes expressed in terms of cultural nationalism: in Poland Wojuech ( $\left.0^{\top} 12\right)$ said 'we are all the Polish nation, so we should all be taught he same, and we all should feel the same as Poles.' In the Slovakian town of Banská Bystrica, there was an extended discussion: 'Every nation has its characteristics, some specific character traits in common,' said Dominika Silke (\$16); 'we are similar in appearance, in our body language,' added Lenka. In Croatia, an Albanian-origin young woman, Agata (Silke (\$17), was critical of the Croats: 'so national, protective, and we have to show our flags, our identity, we have to say we're Croatians, we have to say we're from Rijeka, or from Dubrovnik or something. I don't do that, because I'm both Croatian and Albanian.'

More common among young people were constructivist views of the nation (as Julius exemplified in Odense, and the Stockholm group, above). In Berlin, Silke (\$16) said she 'I wouldn't define someone by his or her nationality - in my opinion it isn't that what makes that person, that gives them an identity - it changes with the places you go to, and the places you like.' In Zagreb, Smiljana (\$15) said nationality 'just means to be born in a certain country, in this instance in Croatia, but I don't think that the nationality is that important to your definition of who you are to me what really matters is what kind of person you are inside. I don't want anyone to think that I don't love my country - I do, in a certain way - but it doesn't represent to me something really important.'

Nationalism was occasionally perceived in highly symbolic terms. In Turkey, the national flag is ubiquitous, and Ege ( $\left.0^{\prime} 13\right)$, on a school trip to Italy from his home town of Tokat, in central Anatolia, was struck by the fact that 'in Italy, there was only one flag in the garden of the school and nothing on the streets, in the parks, like we have here - this shows that their nationality is weaker than ours.'

Some saw the nation in cultural terms, particularly in Italy. For example, in Frascati - a small town just outside Roma - Eusebio ( $\left.\sigma^{\prime} 18\right)$ said that 'culture is the elements that characterise a nation,' and Adalio ( $\sigma^{\prime} 18$ ) spoke of 'all the cultural traditions that each nation has'. In the southern town of Matera, culture was taken to the regional level : Lando (o'17) described Italy as 'a nation in which lived a lot of cultures- the Italian person ... can't be identified as a prototype.' Maud (\$16)linked 'Italian culture and Italian history', and historical issues were particularly employed in several Balkan states to differentiate particular nations from each other and the Turks: in the city of laşi, Dumitru ( $\left.0^{\prime} 14\right)$ said 'I' $m$ a nationalist, because in history [the Turks] conquered several parts of Romania, [they] brought bad things to this country.' Sport could also be an element in national rivalry: Agata (\$17) in Rijeka (Croatia) said that 'in football, or handball, we have to show that we are better. It's meaningless, sport, but when it's Croatia against Serbia, it's more than sport, it's a political issue,' and Tvrtko ( $0^{\prime} 15$ ) added 'we are nationalist ... it has a special charm when we play against Serbia and we win!'

\section{Converging constructions}

The predominance of the view that a sense of national identity was not personally important was striking. In the Stockholm group, Jenny's (\$16) comment exemplifies this: 'I identify myself as a girl, but my national identity is not that important to me - it's not something I usually think of when I think of myself.' But this does not mean that fellow countrymen and women who did 
identify themselves as nationalists were ignored. They were characterised generally as older people, and people from rural areas. Some young people in the more rural areas (particularly settlements of less than 25,000 that were not ethnically diverse) tended to be more essentialist and nationalistic.

There were different aspects to the perceptions of a generational divide. In the Nordic countries, older people's feelings of nationalism were explained in terms of changing traditions and new technologies. In the Norwegian city of Bergen, Kjetil's (o'19) rationalisation of this 'major difference' was that 'young people have experienced the internet, social media, this huge internet era - and because of globalisation, we are much more close to each other than before - we get news from everywhere, and I think people are becoming less and less like nationalistic nationalism has decreased.' In Malmö, Tore (o'15) observed 'our parents and our grandparents are often way more nationalist than we are ... we don't share old Swedish songs and stuff.' In Reykjavik, Elín ( 915 ) thought 'the nation changed in the 50s and 60s ... Iceland became much richer, people got much nicer homes, so I think my grandparents were really proud.' Historical factors were also cited to explain how grandparents and parents might conceptualise the nation in different ways. In Spain, for example, several young people remarked on the patriotism that some of their grandparents expressed as being the consequence of linger affections for the Franco regime. Adriana ( $\$ 12$, Madrid), said 'a lot of time has passed since our grandfathers were born there have been a lot of changes in thoughts ... we don't have the experiences that our grandparents have, we can't think like them.' Aimar's (o'12) 'grandparents [87 and 83] lived through the wars and when it was Franco - they have very different ideas of those of my parents ... they didn't learn my grandparents' ideas, so that's different from what we've been saying to you.' In Finland, the conflicts in 1939 - 1944, with the USSR and Nazi Germany, were part of Altti's (o'16, Jyvaskyla) explanation: 'Seventy years ago, people fought for this country - we haven't seen that - of course they feel differently about this country when they have seen people die for it. 'In some other states, other specific historical reasons were advanced, which are examined in more detail for some states in the following sub-section. Grandparents were particularly identified as different, but in many cases parents were similarly characterised.

Nationalistic feelings were also associated with rural areas in many countries. Leia ( $\$ 16$, Malmö) described 'villages in Sweden where it's very conservative - "you're not allowed to be homosexual, we don't like immigrants" - in cities like Stockholm and Malmö it's easier to be openminded, more people who live here are immigrants.' In Stockholm, Isak (o'16) felt parts of Sweden were moving away from attitudes of tolerance: 'we are on our way from that, to a more nationalist and egocentric way In the Swedish countryside [where] many people think it was much better before, when we had no immigrants ... they want to be really conservative ... they've created this nationalist wave'. The same was true in Slovakia: in the provincial town of Banská Bystrica, Katka (\$17) observed that it was the people living outside the capital who were the most nationalistic. In Amsterdam, Mieke (\$15) made a similar point: the nationalists were 'people more in the villages, where they only have a Chinese [Restaurant] - but always see negative things on TV, that image of all people from other countries [as] intruders, bad.' In Innsbruck, Klaus (o'17) said 'in the Tyrol there are lots of little villages where lots of old people live, and farmers, also young people - and these people don't think about the whole, they just want people from other countries to go back to their country.'

The association made between nationalism, older people and racism was also frequently made. In the Danish town of Haslev, Nis (o'17) said older people may 'be more nationalistic ... because they have lived in Denmark longer than us, and have lived in an era when there had not been much interaction with the world in general. They feel more nationalistic, that they are being invaded by these immigrants.' In Malmö, Tore ( $\left.{ }^{\circ} 15\right)$ described the Swedish Democrat party: 'they are 
nationalists and very often called racists... they want to divide Swedes who are born here from other people. ... For me, being Swedish is not about which culture you have, or where you come from, or actually which language you talk - actually, it's about how you want to identify yourself. Nationalism has become a kind of a bad word here in Sweden right now.'

The extent to which nationalism had become a derogatory term might be indicated by the way that some young people used it as a way of othering other states, of whose policies they disagreed. For example, the United States was differentiated from the Europe Union by Wilfried (o'16) in Berlin: Europe shares some political values with them, but they were 'a special case, because they have a government that is democratic but also incredibly influenced by religion ... and nationalistic views. ... When it comes to political culture, the people there are way more nationalistic than here.' Russia was similarly described, disapprovingly, as nationalist. Marian ( $\left.0^{x} 15\right)$, in the Romanian city of Timişoara, described Russia as 'very conservative, and they are really nationalistic.'

The great majority of young people spoken to in these discussions were dismissive of nationalism. In Haslev (Denmark), Nis (o'17) could say 'I don't look at myself as Danish - I know I'm from Denmark, and ... have a Danish passport - but I'm not very into nationalism.' Troels (o'18) added 'I don't really care about concepts of nations - I care more about the people around me than the nation I'm from.' Ilta (\$19) in Helsinki was 'quite anti-nationalist. I hate it when people emphasise the fact that they're from one specific country - it doesn't necessarily describe who your are at all.'

\section{Contextual constructions}

Although there was a dominating sense that nationalism was seen as outdated, for older people, and often racist, there were many diverse constructions, including variants on this. Contingent factors, at the level of an individual country or a group of countries were significant in contributing to how some young people shaped their sense of the nation. In countries that could narrate a substantial and long historical account, such as Poland, Iceland and Turkey young people sometimes would identify key moments with some sense of national pride. In some countries with a less consistent independent history, young people often expressed less strong identification with the country, as in say Slovakia and Slovenia: and where there was a tradition of independence, as in Iceland and Poland, then this was often foregrounded as a characteristic of national identity. Where there was a narrative of oppression and external dominance, the persistence of a sense of national identity, or survival, was sometimes celebrated and used as a marker to differentiate from a neighbour who became the other (as in the case of Bulgaria with the Ottomans, for example; or Poland and Hungary with the USSR). Where there was a checkerboard of ethnic or national settlements, national identities sometimes became expressed in irredentist terms (such as 'reclaiming' a greater Serbia, or of the Magyarkodo [Greater Hungary] groups): but these were more often described as characteristic of older generations. Where the struggle to establish current independence had been both violent and recent, then there was often a greater sense of specific national identity.

Older people 'have a much greater sense of being together, more bound together as a nation,' said Jolanka (\$15) in Pécs (Hungary), 'because they survived these things together,' referring to both World War 11 and the subsequent Soviet domination. Fábián (o'15) said they had 'experienced what it is like when someone wants to deprive them of their Hungarian nationality.' There were very similar observations in Poland, where some young people followed their elders attachment to the national history of division and oppression: in Warszawa Klaudia (\$16)said she 'felt connected to Poland and to the history, for example, when there are some ceremonies, when 
I recall upon the history of this nation, there is an emotion in me.' On the other hand, some young Poles, such as Rostek ( $\$ 16$, in the same group) rejected this as 'very egotistical - Poles always think that they suffered more that anyone else - we are so patriotic.'

In the Baltic states and in the western Balkans there were particular conditions were families had been caught in boundary changes, so that they found themselves no longer living in their state of origin: those of Russian nationality living in the Baltic states, and those who were formerly Yugoslavians now living in a new Balkan states.

In the Baltic states there were substantial Russian-speaking minorities in Estonia and Latvia, many of whom have a distinctive citizenship status as aliens or non-citizens, with Russian nationality recorded on their Estonian or Latvian passports. Many were regarded with suspicion by young Estonians and Latvians: they retained their Russian language, attended separate schools. In Latvian and Lithuanian schools that had both Latvian or Lithuanian pupils and russkiye and part-russkiye students, there was a large degree of acceptance and minimising of difference. This was not so where there were separate language schools in Estonia and parts of Latvia, exacerbated by fears of being taken again by Russia (the examples of Georgia and the Ukraine being mentioned). Many Russians had integrated, however: in Jūrmala, Matiss (o'13) was proud to be Latvian: 'I am Russian - I am born in Latvia, and I feel like a Latvian. I speak pretty good Latvian, my friends are Latvian, and my dad is Latvian. ... I don't feel I am Russian.' Monta (\$15) (also with a Russian mother), was more ambivalent : 'I don't think I'm Russian, but I also don't count myself Latvian.'

Brubaker (1996) characterised these Baltic Russians, and similarly placed internal migrants in Yugoslavia, as reframed: finding themselves potentially reclassified as non-nationals in a state that had just come into existence. The animosities in the Balkans were longstanding, reflecting both Bosnian-Serbian differences in World War Two and the subsequent Serbian hegemony in Tito's Yugoslavia and in the wars of the 1990s. One school in Ljubljana, Slovenia, had many young people of Serbia, Croatian and Bosnian origins, some of whom felt ostracised because of these histories. Ana (\$12, of Serbian heritage) said some young Slovenes 'still are very much focussed on the past, and according to this they are blaming people.' They particularly emphasised how it was their grandparents, and sometimes their parents, who were nationalistic,: Nika (120'), Montenegrin origin) said 'the older they are, the more religious they are, and the more nationalist,' and Ema (\$ 12, Slovene/Croat) said 'my grandfather is Croatian, and he feel this stronger than being Slovenian, though he lives in Slovenia.' This lead sometimes to problems in school - 'not always,' said Žiga (o'13, Serbian origin), 'there are always good people, no matter from which nationality, from which country. Because of the wars, when their parents are mad with other nationalities, like Serbia and Bosnia, and they think that Serbia, for example, is a bad country, and then they teach their kids to think the same way as they do. So there are problems like that in school, they don't want to be friends with you.'

There were similar issues in Croatia, with young people's sense of nationalism vicariously refracted through their parents' experience of the war of independence (1991-95, against the 'Yugoslav' Serb forces). In Zagreb, Radoš (o'14) said he didn't care much about his Croatian nationality 'because I was not affected by the war. I was just born in independent Croatia - it doesn't affect me in any way.' Morana (\$14) differed. 'My dad was in the war - he is alive, thank God - but he went through really a lot, and I am proud of him, really grateful, and I think that all Croatians should be. He was ready to sacrifice his life for the country and the next generations - it's a shame when a young Croatian says that he doesn't feel anything about our history.' But the war had only directly affected a minority, and most young people were less concerned with nationality (Ross, Puzić and Doolan, 2017). 
One final, and rather different, example of a contextual variation came from Norway, where some group discussions took place in 2014, two years after the massacre of 77 young people at Utøya by the far-right terrorist Anders Behring Breivik. Some of the young people had friends who had been involved, or had fortuitously missed attending the event. They stressed how their sense of Norwegian nationality had been enhanced by the state and country's reaction to the event: Lovinda (\$ 17), in Lillehammer, said 'we stand together as a nation - when we had the terror thing a couple of years ago, we all went together with roses, and you kind of felt - it was so Norwegian everyone stood together, and no one was angry in that way that we wanted to hurt other people, or be mean and unfair. I felt - it's kind of weird to say - but I felt we became closer as a nation. I love my country even more because of the way we handled everything.' Kine (\$18) added 'you know, just holding each other's hands, hugging - being there for each other in that difficult time.' Lovinda then suggested that 'If this had happened in America, he would have got the death sentence right away - but in Norway we treat everyone with respect, and everyone has their rights.'

\section{Discussion}

In general, young Europeans in this age cohort, at this time, were critical of the concept of having a 'national identity', which they associated with far-right wing political parties and (often) older people. They did, however, show some identification with their country, and often with the sociopolitical structures of their state, such as health and welfare provision, which was sometimes contrasted favourably with the situation in United States. Citizenship identity was not infrequently seen as a matter of chance, rather than as an essentialised construction of national characteristics. There was little evidence of variations between classes or genders on the issues of nationalism, though there were on other issues not considered on this article (for instance, young men and more middle-class young people tended to initially construct Europe in instrumental terms of freedom to travel and study).

Their identities were seen as with a wide spectrum of political locations, from the institutions of the local area, sometimes the province, the state and with Europe, and sometimes global. Europe was constructed as an identity by many young people, initially in the discussions as an instrumental identity (giving freedom of travel, perhaps for work, but more often for education); but as discussions continued Europe was seen as a location for valued and rights that they considered important. These tended to be rights that were still sometimes matters for dispute, in Europe and in other states in the world - concerning, for example, women's rights., LBGT issues, refugee and migrant rights, and anti-racism. 'Nationalism' was seen as explicitly constructed, as a mythic story that was no longer needed as a social narrative. Nationalist parties were frequently mentioned, almost always in negative terms: there appeared to be very little evidence of young people supporting extreme nationalist parties.

There were contextual exceptions to these generalisations. In some western Balkan states, and in Turkey, there was often an essentialised construct of nationality, with references to lineage and blood lines. Some of this arose from memories of recent conflicts, especially in the western Balkans, and some from more distant recollections of combat. This was sometimes linked to symbols such as the national flag, for example in Turkey.

But there were particular local turns to all of these understandings of nationalism as a construct. In the Visegrád states, for example, there was a real awareness of why previous generations had developed and tenaciously clung to the myth of the unitary and homogeneous nation: it was such beliefs that held their grandparents' generation together in the face of the Nazi invasion of the 1940s, and when the USSR dominated the region during the Cold War. But the young people of this study largely appeared to feel that this sense of a nation was now outmoded, and unnecessary 
now their state was firmly within the European Union and NATO. While the nation was generally seen as passé, this did not mean that most young people did not show an affection for their country, and an appreciation of the state they lived in (the latter particularly evident in Scandinavia and north-western Europe); but most of them distinguished this from, and disavowed, nationalism.

And a construct of Europe - hazily defined, taking in aspects of both the European Union and the Council of Europe - appears to be emerging in the minds of many young people of a community, defined by some shared political and social values, rights-based, fluid and at times fractious. This is not another form of the nation, nor of a state, but it has elements of the imagined community of Benedict Anderson: Olesia's (a 12 year old Polish young woman in Kraków) description of feeling European was that:

everywhere you go you are surrounded by your friends, people from the same group - I can go anywhere, to any country and they would know ... you are from Europe. They don't know you, but they know you - you are like a distant relative. Being European means that everywhere you have neighbours ... In Europe, everyone has awareness, they know about each other, where each country is.

This European dimension appears to constitute an additional identity, but, I would suggest, is not in itself responsible for the rejection of nationalism. There were no references to 'European citizenship' as such, or any analogous term: the Maastricht/Lisbon creation of a European Citizenship did not appear to register with any of the groups. Yet Goethe's 1792 observation of the 'new epoch' of world history, in the European context, appears to have lasted little more than two centuries. 


\section{Acknowledgments}

My travel and subsistence costs for most of the fieldwork in 2010-12 were supported by Jean Monnet chair grant from the European Commission, award 2009-3226/001-001. In 2014 I also received a small grant from London Metropolitan University to cover my fieldwork expenses for the autumn of 2013. All other expenses were met personally. I received ethical approval for the research from London Metropolitan University in November 2009 and in June 2014.

\section{Declaration of interest}

I have no interests, financial or through other benefits, that arisen from the direct applications of this research.

\section{Biographical Note}

Alistair Ross is an Emeritus Professor at London Metropolitan University, where he worked from 1985 to 2009. He was awarded a Jean Monnet ad personam chair by the European Commission in 2009, have formed and led the Erasmus Academic Network Children's Identity and Citizenship in Europe from 1998 - 2008. At London Metropolitan he was founder and Director of the Institute of Policy Studies in Education from 2000 to 2009. He has written widely on research for education for social justice and equity, on citizenship education and learning in Europe and the curriculum. Books include Curriculum: Construction and Critique (Routledge 2000); Higher Education and Social Class: Issues of exclusion and inclusion (with Louise Archer and Merryn Hutchings (Routledge 2003); A European education: Citizenship, identities and young people (Trentham 2005); Understanding the Constructions of Identities by Young New Europeans: Kaleidoscopic Selves (Routledge 2016) and Finding Political Identities: Young People in a Changing Europe (Palgrave Macmillan 2019).

\section{Data availability}

All recordings of the discussions have been transcribed, and have not yet been archived because they are still being added to and further analysed by the writer. The original audio recordings have been deleted. Records and consent forms from parents and young people that contain material that would identify them are being securely held in the archives of London Metropolitan University until 2026, when they will be destroyed.

\section{References}

Agafiţei, Mihaela and Georgiana Ivan. (2016). First and Second-Generation Immigrants - Statistics on Main Characteristics. Luxembourg: European Commission, Eurostat. http://ec.europa.eu/eurostat/statistics-explained/index.php/First and secondgeneration immigrants - statistics on main characteristics\#Data visualisation

Anderson, Benedict. (1983). Imagined Communities: Reflections on the Origin and Spread of Nationalism. London: Verso.

Anthias, Floya. (2012). "Transnational Mobilities, Migration Research and Intersectionality: Towards a Translocational Frame." Nordic Journal of Migration Research 2 (2): 102-110.

Arnett, Jeffrey. (2008). "The Neglected 95\%: Why American Psychology Needs to Become Less American." American Psychologist 63 (7): 602-614.

Balescu, Oana. (2009). "Reflections on European Identity: The Case of East European Countries." In European Citizenship - In the Process of Construction - Challenges for Citizenship, Citizenship Education and Democratic Practice in Europe, edited by Ditta Dolejšiová and Miguel Angel Garcia López, 44-54. Strasbourg: Council of Europe. 
Bhabha, Homi. (1990). "DissemiNation: Time, Narrative, and the Margins of the Modern Narration." In Nation and Narration, edited by Homi Bhabha, 291-322. London: Routledge.

Bohnsack, Ralf. (2000). Rekonstruktive Sozialforschung. Einführung in die Methodologie und Praxis qualitativer Forschung. Opladen: Leske and Budrich.

Bourdieu, Pierre (1984). Distinction: a social critique of the judgement of taste. London: Routledge.

Brass, Paul. (1979) "Elite groups, symbol manipulation and ethnic identity among the Muslims of South Asia". In David Taylor and Malcolm Yapp (Eds.) Political Identity in South Asia (pp 35 77). London: Curzon.

Brubaker, Rogers. (1996). Nationalism Reframed: Nationhood and the National Question in the New Europe. Cambridge: Cambridge University Press.

Bruter, Michael. (2005). Citizens of Europe? The Emergence of a Mass European Identity. London: Palgrave Macmillan.

CEC (Commission of the European Communities). (1976). "European Union: Report by Mr Leo Tindemans, Prime Minister of Belgium to the European Council." Bulletin of the European Communities, Supplement 1/76. (University of Pittsburgh Archive of European Integration.) http://aei.pitt.edu.

CEC (Commission of the European Communities). (1992). "Treaty on European Union, Signed at Maastricht on 7 February 1992." Official Journal of the European Communities C 19135. European Commission: Brussels.

CEC (Commission of the European Communities). (2008). "Consolidated versions of the Treaty on European Union and the Treaty on the Functioning of the European Union." Official Journal of the European Communities C 115 51, European Commission: Brussels.

Charmaz, Kathy and Linda Belgrave. (2010). "Qualitative Interviewing and Grounded Theory Analysis." In The Sage Handbook of Interview Research: The Complexity of the Craft, edited by Jaber Gubrium, James Holstein, AmirMarvasti and Karyn McKinney, 247-366. Thousand Islands, CA: Sage.

Connor, Walker. (1978b). "Ethno-national versus other forms of group identity: the problem of terminology". In Nic Rhoodie (Ed.) Intergroup accommodation in Plural Societies. (pp 53-82) London: Macmillan.

Connor, Walker. (1978a). "A Nation Is a Nation Is a State, Is an Ethnic Group, Is a ... ." Ethnic and Racial Studies 1 (4): 379-388.

Connor, Walker. (1993). Ethnonationalism: The Quest for Understanding .Princeton, NJ: Princeton University Press.

Duchesne, Sophie. (2008). "Waiting for a European Identity ... Reflections on the Process of Identification with Europe." Perspectives of European Politics and Society 9 (4): 397-410.

Ekström, Mats. (2016). "Young People's Everyday Political Talk: A Social Achievement of Democratic Engagement." Journal of Youth Studies 19 (1): 1-19.

Fulbrook, Mary. (2011). Dissonant Voices: Generations and Violence Through the German Dictatorships. Oxford: Oxford University Press.

Gellner, Ernest. (1983). Nations and Nationalism. Ithaca: Cornell University Press.

Glaser, Barney and Anselm Strauss. (1967). The Discovery of Grounded Theory: Strategies for Qualitative Research. London, UK: Weidenfeld and Nicolson. 
Gugglberger, Lisa, Michaela Adamowitsch, Friedrich Teutsch, Rosemarie Felder-Puig and Wolfgang Dür. (2015). "The Use of Group Discussions: A Case Study of Learning About Organisational Characteristics of Schools." International Journal of Social Research Methodology 18 (2): 127143.

Halle, Louis. (1952). Civilisation and Foreign Policy. New York, NY: Harper and Row.

Henrich, Joseph, Steven Heine and Ara Norenzayan. (2010). "The Weirdest People in the world?" Behavioural and Brain Sciences 33 (2-3): 61-83.

Herder, Johann. (2002). Philosophical Writings. Translated by Michael Forster. Cambridge: Cambridge University Press.

Hobsbawm, Eric and Terence Ranger (Eds). (1983). The Invention of Tradition. Cambridge: Cambridge University Press.

Hoskin, Geoffrey and George Schöpflin (Eds). (1997). Myths and Nationhood. London: Hurst.

Joppke, Christian. (2010). Citizenship and Immigration. Cambridge: Polity.

Loos, Peter and Burkhard von Schäffer. (2001). Das Gruppendiskussionsverfahren.Theoretische Grundlagen und empirische Anwendung [Group Discussion Procedures: Theoretical Basis and Empirical Application]. Opladen: Leske and Budrich.

Lutz, Wolfgang, Sylvia Kritzinger and Vegard Skirbekk. (2006). "The Demography of Growing European Identity." Science 314 (5798): 425.

Noiriel, Gerard. (1996). The French Melting Pot: Immigration, Citizenship and National Identity, (Trans. Geoffroy. de Laforcade from Le Creuset français. Histoire de l'immigration (XIX $-x X^{e}$ siècle) (1988), Paris: Seuil). Minneapolis MN: University of Minnesota Press.

Opello, Walter. (2016). War, Armed Force, and the People: State Formation and Transformation in Historical Perspective. Lanham MD: Rowland Littlefield.

Rabiee, Fatemeh. (2004). "Focus-Group Interview and Data Analysis." Proceedings of the Nutrition Society 63 (45): 655-660.

Rochat, Philippe. (2010). "What Is Really Wrong with a Priori Claims of Universality? Sampling, Validity, Process Level, and the Irresistible Drive to Reduce." Behavioural and Brain Sciences $33(2 / 3)$ : 107-108.

Ross, Alistair, Saša Puzić and Karin Doolan. (2017). Balkan and European? Place Identifications of Young People in Croatia. Revija za Sociologiju. 47(2) 125-150

Ross, Alistair. (2015). Understanding the Constructions of Identities by Young New Europeans: Kaleidoscopic Selves. London: Routledge.

Ross, Alistair. (2019). Finding Political Identities: Young People in a Changing Europe. Cham: Palgrave Macmillan.

Rozin, Paul. (2001). "Social Psychology and Science: Some Lessons from Solomon Asch." Personality and Social Psychology Review 5 (1): 2-14.

Rustow, Dankwart. (1967). A World of Nations. Washington, DC: Brookings.

Scheunpflug, Annette, Susanne Krogull and Julia Franz. (2016). "Understanding Learning in World Society: Qualitative Reconstructive Research in Global Learning and Learning for Sustainability." International Journal of Development Education and Global Learning 7 (3): 623.

Shachar, Ayelet. (2009). The Birthright Lottery: Citizenship and Global Inequality. Cambridge, MA: Harvard University Press. 
Van den Berghe, Pierre (1979) Race and Ethnicity: A Sociobiological Perspective. Ethnic and Racial Studies. I (4) 401-411.

Von Goethe, Johann Wolfgang (1822) [1999] Aus meinem Leben. Auch ich in der Champagne. [From my Life: Myself in Champagne; commonly known as Kampagne in Frankreich 1792 [The campaign in France 1792]]. Stuttgart: Cotta. Reprinted (1999) Complete Works, Vol 10: Autobiographical Writings II. Hamburger Ausgabe. Munich: Beck.

Wagener, Marina. (2018). "What Do Young People Learn When Sponsoring a Child in the Global South? Empirical Findings on Learning Experiences of Young Sponsors in Germany." International Journal of Development Education and Global Learning 10 (1): 90-102.

Word count (abstract, article, references) 8770 